\title{
THE BRITISH COLUMBIA ENERGY COMMISSION NATURAL GAS FIELD PRICE AND INCENTIVES INQUIRIES
}

\author{
PETER M. STEELE*
}

\begin{abstract}
The author outlines the structure and scope of the British Columbia Energy Commission. He then discusses whether the resurgence in exploration and development activity in the 1975-76 drilling season was attributable to the government's implementation of the Commission's recommendations. He outlines some major changes causing the turn-around in the industry, particularly the introduction of the Exploration and Development Fund Credit program. Finally, he comments on the effectiveness of the changes and evaluates the service of the Commission to the industry and the province.
\end{abstract}

On February 27, 1975 the Lieutenant-Governor-in-Council directed the British Columbia Energy Commission ("the Commission") to undertake an analysis of the province's natural gas industry, specifically to review:

(a) present levels of exploration and production in the natural gas industry within the province;

(b) present and future field prices for natural gas in the province and whether such prices represent fair compensation to the producers of natural gas and constitute adequate incentive for exploration and development of natural gas within the province;

(c) any other factors which may influence the rate of exploration, development and production of the natural gas resources of the province and measures which may appear desirable to accelerate such exploration, development and production having regard to the public interest. ${ }^{1}$

Such an analysis falls squarely under the provisions of section 20 of the British Columbia Energy Act, R.S.B.C. 1973, c. 29, (the "Energy Act") the enabling legislation which was passed by the Legislature on April 7, 1973.

This legislation bears further scrutiny before considering the "Pricing and Incentives Inquiries" in more detail. It created a government agency different in form and substance to the previously existing Public Utilities Commission established under the Public Utilities Act, R.S.B.C. 1960 , c. 323 . The Public Utilities Commission, which was disbanded by the Energy Act, was previously charged only with the regulation of utilities in the province. The Commission, under Chairman Dr. Andrew Thompson $^{1 \mathrm{a}}$ and commissioners John Ludgate and Donald Johannessen, head up a professional and support staff of thirty-two as of December, 1975,2 who are charged with carrying out the following functions as set out in the ascribed Parts of the Energy Act:

Part II Energy Resource Management

Part III Regulation of Energy Utilities

Part IV Regulation of the Petroleum Industry

Each of these areas have their separate staff who function not only independently of each other but who are also able to function as an

\footnotetext{
- Assistant Secretary and Solicitor, Westcoast Transmission Company Limited, Vancouver, British Columbia.

1. British Columbia Order-in-Council 760, issued February 27, 1975.

1a.Dr. Andrew Thompson resigned as Chairman of the Commission effective July 1, 1976. He is now a member of the Faculty of Law at the University of British Columbia.

2. British Columbia Energy Commission, Third Annual Report for the year ended December 31, 1975, page 1.
} 
independent research and advisory adjunct to the Commission or the government itself. The staff neither participates in the decision-making or policy-setting functions of the Commission nor that of the Legislature.

Mr. J. David V. Newlands is in charge of the regulation of energy utilities. His staff of seven have strong business and accounting backgrounds. Their concern lies mainly in the short-run availability of energy and its cost to the province for periods of up to two years. Apart from the obvious regulation responsibilities of twenty utilities which included six applications for rate increases in 1975, this department has prepared position papers on the Mackenzie Valley Pipeline Hearings and interventions to TransCanada's recent rate hearing, conducted research concerning projected oil pipelines in British Columbia, heard applications for local distribution franchises in the province, and are now even charged with the regulation of Westcoast Petroleum Ltd. and the Okanagan Telephone Company. This department encourages a wide variety of input and ideas to be brought before the Commission to provide it with the best possible perspective for its decisions. In so doing it seeks to assist companies in their applications to the Commission and thereby minimize consultants' costs, which are ultimately tracked through the consumer.

This department also hears the complaints made against utility companies, including British Columbia Hydro and Power Authority ("B.C. Hydro"). Section 156 of the Energy Act gives the Commission authority to investigate complaints of discrimination by B.C. Hydro related to price or supply of gas and electricity. B.C. Hydro, however, invariably questions the jurisdiction of the Commission and this is a question which has not yet been settled. In total, there were thirty-six complaints in 1975, not counting twelve meter error complaints, of which only seven were against B.C. Hydro. The largest number concerned West Kootenay Power and Light Company, Limited. The latter complaints basically related to the cost of extending electrical service. In this connection the department prepared a report for the government on the "Jurisdictional and Safety Aspects of Gaseous Fuel Distribution in the Province".

The Regulation of Petroleum Industry Department is to date the least publicized of the three departments, yet it is anticipated to have increasing impact on the British Columbia consumer. It is headed by Mr. Robert T. Green, a chemical engineer who supervises a staff of four economists. It has recently completed a two and one-half year study on petroleum marketing. This report is an extension and up-date of the 1966 Morrow Commission Report in British Columbia and the 1968 McKenzie Commission Report in Alberta. The report was released at the beginning of June, 1976. It contains recommendations on the geographic extension of competition and is expected to have a significant impact on government policy. However, to date no major government has been taken on this report.

This department has also conducted a hearing into the rapid increase in propane prices and this report should be tabled with the government shortly. It has also set down petroleum pricing product guidelines which are presently only limited to gasoline and heating oils. The general attitude of this department is that there is only so much disposable income available to any consumer and the amount paid for energy must be in line with an overall efficient use of income. 
Mr. Green's department also handles consumer complaints which in 1975 included approximately four hundred letters and phone calls. In addition, it monitors national and world conditions to keep the Commission informed in an attempt to secure the best possible result for the British Columbia consumer.

The Energy Resource Management Department is the department with which we are concerned in looking at the Natural Gas Field Price and Incentives Inquiries. It is supervised by Dr. Anthony J. Hepworth, P.Eng., with the assistance of one engineer and seven economists, most of whom have their master's degree. Their main concern is the medium to long-run supply of energy resources in British Columbia. Their interest in the short-run supply is only as it relates to the province's future requirements. They are responsible for supply/demand forecasts and pricing and energy forecasts which focus on natural gas, oil, electricity and coal. Recently this department has prepared submissions to the National Energy Board Hearing on Canadian Supply Requirements and have prepared position papers for the government on the proposals of Canadian Arctic Gas Pipeline Limited, Foothills Pipeline Limited and the 'Alcan Oil Pipeline' of Trans-Mountain Oil Pipe Line Company.

On April 7, 1975 a public hearing was held establishing the scope and procedure for the 1975 inquiry and on June 12, the Commission commenced twenty.two days of hearings which included two days in Fort St. John focusing on the effects of the drilling and exploration slowdown on the general economy of northeastern British Columbia. Fifty-seven intervenors were heard.

A detailed review of the submissions of all of the intervenors would only duplicate the summaries already adequately presented in the commission's Final Report last October. ${ }^{3}$ The major inescapable conclusion, however, was that exploration and development work in the province by petroleum companies, large and small, had virtually skidded to a standstill. Without the continuation of this activity future reserves, which most parties concurred were still available, would not be drilled and the supply of natural gas and petroleum products generally would decrease whether considering just British Columbia use or export as well.

My purpose here is not to review the variety of estimates given for the reserves still to be proven, nor the projected accretion of trend gas, nor the estimate of future shortages. The facts were clear that gas is available to be found but the companies concerned no longer found the prospects of further exploration or development economically feasible. Conflict between the taxing policies of the federal and provincial governments created a net return to the producing companies lower than could be expected in Alberta. Promises from British Columbia of tax indemnification were not clear and the confidence of the producing companies towards investment in British Columbia reached a precariously low level.

By August 20, 1975 the Commission issued an interim report encouraging government action to spur exploration and development activity during the $1975-76$ drilling season. The final report was submitted in October-a Summary of Findings and Recommendations is 
attached as Exhibit $\mathrm{A}$. The report was accepted by the government and changes were made in British Columbia policy.

What was the result of these recommendations? Exploration and development activity has certainly not remained at a standstill. After a lag period extending until January, 1976 the number of wells completed and drilling rigs in operation increased dramatically in comparison to January, 1975. The table and graph in Exhibit B following this paper show this change more fully but nonetheless the difference between wells completed and drilling rigs in use in 1975 and 1976 is sufficient evidence to reveal a major change in attitude and renewed confidence by the producing companies to make undertakings in British Columbia.

Although the bulk of the activity this past winter was still in Alberta, with one thousand four hundred and seventeen well completions, British Columbia up to the beginning of April showed eighty-six well completions in comparison to fifty-eight for the same period in the previous year.

Was this resurgence the result of the government implementing all of the recommendations of the Commission? If not, which were implemented and which were not?

First, those which were not. Both Commission recommendations to establish a Crown corporation for gas exploration and development and for government co-ordination of the provincial environmental protection agencies have not been carried out. The present impression is that the new government ministers, the Honourable Jack Davis for Energy (and thereby the Commission) and the Honourable Thomas Waterland (and thereby the British Columbia Petroleum Corporation (the "Petroleum Corporation")) do not consider these matters to be a priority. Activity has resumed in the industry and as a collection agency the Petroleum Corporation has been most successful. Better, therefore, at this point in time to leave untouched the structure and responsibilities of these government agencies.

This attitude also covers many other proposals contained in the submissions to the 1975 Inquiry. Such suggestions included permitting a higher rate of take, regional pricing, purchasing of reserves in the ground by the Petroleum Corporation to reduce holding costs, the payment of royalty on a net value basis rather than on gross value and various bidding systems for land or exploration rights. The fact that no action has been taken so far on any of these proposals does not mean they have been rejected completely. It is just that the government feels that their implementation is not needed at the present time.

Actions that have been taken include the fact that prepayment advances so optimistically promoted by the Petroleum Corporation were suspended November 1, 1975. Some projects still proceeded under such arrangements but these were only ones in which commitments had been previously made.

What has caused the turn-around in the industry? Two significant but inter-related changes have occurred: a maximum of fifteen cents increase in the price paid for natural gas at the wellhead coupled with the introduction of an Exploration and Development Fund Credit program by which a producer may earn an increased price for old gas. ${ }^{4}$

4. Supra, n. 3, Appendix B; "old gas" is gas from pools producing prior to October 31, 1974; "New gas" is gas from pools commencing to produce on or after November $1,1974$.

Schedule C Memorandum of Agreement, page 2: “. . . it being agreed that New Gas is raw gas which comes 
The details of this credit program were attached as a Memorandum of Agreement and Schedule $C$ to all gas purchase contracts between producing companies and the Petroleum Corporation (see Exhibit C attached).

The Commission in its final report had recommended that the increase in the wholesale price of natural gas be twenty-five cents. This figure was rejected by the government and a fifteen cent compromise was introduced effective November 1,1975 . The price on new gas to be found after such date was increased the said fifteen cents but on old gas the increase had to be earned as a rebate of seventy-five percent of the expenditures made by a producing company in British Columbia for exploration or development work. The goal of the Commission thereby was to encourage the resumption of a level of investment expenditure at least equal to that which existed prior to 1974 .

The rebate was established as a system by which a producer through certain expenditures or by undertaking defined types of work could earn credits redeemable for cash. This program provided retroactivity to September 1, 1975 for the earning of such credits.

The key to the program lies in the definitions of Allowable Cost and Allowable Work permitted for the earning of credits. Simply, "Allowable Cost" is any reasonable cost incurred in doing "Allowable Work". It includes any capital expenditure accepted under generally recognized accounting principles but does not include the cost of money for financing such expenditures. Although overheads are permitted only for supervision in the field, a ten percent allowance is permitted for administration. If, however, the expenditure has been for machinery or equipment which is not used in the province for four years then a portion of the cash rebate received relating to its purchase must be returned to the Petroleum Corporation upon its removal from the province. An allowance is given for the work done using such equipment or machinery prior to its removal and equivalent volumes relating to the rebates returned on these items may be used to earn other credits for future redemption.

The definition of "Allowable Work" covers a broad scope of effort. Briefly it includes all drilling expenditures, installation of compression facilities, pumps, meters, dehydrators, conservation plants and field work covering any geophysical survey.

These definitions are not related only to expenditures or work in connection with natural gas. They also include all aspects of exploration and development for oil. This credit program therefore encourages activity in both fields of the petroleum industry and expenditures for oil can be used as a qualification for a credit redemption earned from natural gas production.

The mechanics of the system are not difficult. Each producer selling old gas to the Petroleum Corporation is permitted to earn a rebate of up to fifteen cents per Mcf. The only limit is the volume of old gas production sold and as mentioned, only seventy-five percent of Allowable Cost or Allowable Work is eligible for credit. Therefore twenty cents must be expended for a fifteen cent credit.

within one of the categories (that is, one of the classes of gas described in the price policy letter dated November 21, 1974) which as of the 1st day of January, 1975, took a price on sale to the buyer of not less than 23e per mef of residue gas derived therefrom, and Old Gas is raw gas which does not qualify as New Gas." 
These credits must be earned either within the year the old gas is produced or the immediate three years following. If earned within the year created or the year following they are worth the fifteen cents per Mcf figure mentioned. If, however, the expenditure to which the production relates is not until the second or third year after, the credit available drops to seven and one-half cents per Mcf. Once earned, however, redemption need not be in the year it is earned. The credit once earned is termed to be a "locked-in credit".

Unfortunately as of the date of the preparation of this paper the success of this program could only be measured in terms of the increased activity this past winter. The Commission, however, views this increase optimistically especially considering the lag period which was necessary for the renewed drilling activity to commence. The true measure of the success, however, will only be known when the Petroleum Corporation begins to receive credits for redemption. Then the participation by the industry can be accurately measured. Redemption of credits was permitted to commence April 1, 1976 but by the end of April only two applications had been received. The Petroleum Corporation attributes this delay to the necessity of compiling substantial documentation to properly support redemption applications. The amount of lag thereby is one aspect of the program which is being carefully monitored.

Another quality of the exploration credits is their transferability. It was hoped thereby that if a producer is earning credits through its production of old gas in British Columbia but not embarking on exploration or development activity sufficient to support redemption of these credits, it may transfer them to another producer whose Allowable Work or Allowable Costs could support redemption for credits exceeding the amount of credits it has earned for its old gas production. In this manner an individual producer is not locked into further exploration and development activity in British Columbia to gain the total benefits of his credits. At the same time a producer who is planning projects in British Columbia is not prejudiced if his production of old gas does not keep pace with such expenditures.

It should also be noted that the inter-relationship of the program between oil and natural gas activity is not one-sided. It extends to a similar credit arrangement for the production of old oil. Under British Columbia Reg. 737/75 new Petroleum and Natural Gas Royalties Regulations became effective November 10, 1975. The definitions of Allowable Cost and Allowable Work in these regulations correspond to the ones concerning natural gas found in the said Memorandum of Agreement and Schedule $\mathrm{C}$ to the Petroleum Corporation purchase contracts. Similarly, it is the definitions of "old oil" and "new oil" in these regulations which is important. These are: 5

"old oil" means crude petroleum or field condensate that is not classified as new oil; "new oil" means any crude petroleum or field condensate produced through a well completed subsequent to October 31,1975 , but does not include petroleum produced from:

(i) a new pool discovery well completed subsequent to October 31,1975 , during the three years immediately following the date the well started to produce petroleum;

(ii) an additional well completed in a spacing area where the initial well was completed prior to November $1,1975 \ldots$. 
Credits under these regulations may also be earned commencing September 1, 1975 with April 1, 1976 being the first day on which redemption payments may be made by the administrator who is the director of mineral revenue appointed under the Public Services Act. The previous comments concerning a delay in applications being received by the Petroleum Corporation for redemption of credits also apply to applications to the administrator for the redemption of credits from old oil production. It should be noted that the administrator has delegated the operation of the oil production redemption program to the Petroleum Corporation. That agency thereby handles all redemption applications.

The credit earned on old oil production is seventy-five cents per barrel and if not earned against expenditures in the year of production or the year following it drops to thirty-seven and one-half cents for the second and third years. As with natural gas production, if the credit is not earned by the end of the third year after, possible rebate on such production expires. The seventy-five percent redemption limit on Allowable Costs or Allowable Work also applies.

The flexibility of the credit program should now be evident. Production from oil or gas can create credits which may be matched to expenditures in both oil and gas activity. As with the natural gas scheme credits earned by old oil production may be transferred between producers.

The Petroleum Regulations for oil production, however, also provide for new royalty calculations which on the average result in a three percent reduction in royalty payments. The Exploration and Development Credit Fund, if utilized, is structured to provide further ten percent reduction on the average, thereby providing an average possible royalty reduction of thirteen percent over the regulations affective before November 10, 1975.

It should be noted at this point the reason for two separate but interconnected programs. Prior to the tax conflict between the federal and provincial governments both oil and gas incentive programs could have been formulated under the Petroleum and Natural Gas Royalties Regulations. These Regulations now provide as part of a tax indemnification arrangement that all gas sold to the Petroleum Corporation is exempt from the payment of royalties. In so doing all such gas, which now accounts for all natural gas produced in British Columbia which enters into the Westcoast system, is outside the framework of the Petroleum and Natural Gas Royalties Regulations. The exploration credit program now attributable to such gas is thereby found in the said Memorandum of Agreement and Schedule C (see Exhibit C hereto).

It is interesting to note one main difference between the two programs which may present procedural difficulties at a later date. Under the Petroleum Regulations any disputes are to be referred to the Minister of Mines and Petroleum Resources whose decision shall be final. Under Schedule $C$ the gas purchase contracts disputes are to be settled by arbitration under the Arbitration Act of the Province of British Columbia.

In Appendix B of the Final Report of the 1975 Inquiry the British Columbia Energy Commission stated that it would undertake: 6 
... an annual review of natural gas and crude oil field prices and will recommend prices and royalty schedules to be effective the following November 1st that reflect cost changes, changes in rates of inflation, changes in producer realizations in Alberta and elsewhere, changes in federal taxes, changes in export and domestic prices, the adequacy of British Columbia supplies and the need for an appropriate level of incentives to ensure a rate of exploration and development expenditures that is in the public interest of the citizens of the province.

On March 18, 1976 the Secretary of the Commission advised that a public hearing would be held in late May or early June to review: ${ }^{7}$

(a) present levels of exploration and production in the petroleum and natural gas industry within the province;

(b) present and future field prices for petroleum and natural gas in the province and whether such prices represent fair compensation to the producers of natural gas and constitute adequate incentive for exploration and development of natural gas within the province;

(c) any other factors which may influence the rate of exploration, development and production of the petroleum and natural gas resources of the province and measures which may appear desirable to accelerate such exploration, development and production having regard to the public interest.

The Commission also invited producers to comment on the effectiveness of the changes made following the 1975 Inquiry. The hearing commenced on June 14, 1976.

At the time this paper was originally prepared, comments on the issues the Commission expected to have raised were included. By the time of the delivery of the paper all submissions were filed and some of the significant views presented at the 1976 hearing were that:

a. the net return to the producers operating in British Columbia is still not sufficient.

b. it is acknowledged that there is an increase in exploration and development activity in British Columbia but such increase is mainly the result of an evidence of good faith by the last price increase and only with the expectation of future increases as the border price and the Toronto city gate price increases.

c. the rate of finding of natural gas is not meeting the rate of consumption in British Columbia and the province's surplus even respecting domestic use will end unless exploration activity increases.

d. the present scheme of Tax Indemnification in British Columbia is vague and cumbersome and does not encourage confidence in producing companies.

e. the Exploration and Development Fund Credit system is not successful because:

(i) it does not increase the price of old gas, it simply reduces exploration and development costs;

(ii) it rewards activity not success;

(iii) it has a built-in payment delay which results in producing companies incurring interest costs;

(iv) transferability does not work because producing companies with surplus credits have difficulty valuing such credits and are unwilling to sell them in case future production might render them valuable to the company. 
f. the previous royalty system is favoured with the most frequent recommendation being a thirty-five percent retention royalty for the producer after wellhead costs. Presently some companies revealed that they were receiving no return and the highest reported only twelve percent on a discounted cash flow basis.

g. the net back to the producer for both oil and gas must be at least comparable to Alberta and one submission placed the differential between the two provinces as being as high as one-third.

h. it must be recognized that the most prospective areas are explored and developed first with costs increasing incrementally as activity broadens or continues over time.

i. there should be a set method to track through to producers part of future price increases. Some submissions felt it was premature to develop a flow through formula, while others advocated formulas such as used by the Alberta Petroleum Marketing Commission.

j. oil prices should be encouraged to rise to world prices and natural gas should be priced equivalently on a commodity price basis.

k. all gas should receive the same price and thereby provide a better cash flow for exploration and development expenditures which can not be financed by borrowings.

1. one submission advocated an exploration incentive scheme in which fifty percent of exploration expenses are credited against royalty payments up to a maximum of twelve percent in any one year and excess exploration credits may be carried forward and used to offset future royalty payments.

m. pipeline connections should be made to wells previously considered uneconomic because such connections will generate drilling activity in such areas and produce reserves which will make such connections economic.

n. the social services tax (sales tax) should be removed on materials and equipment used in the exploration and development of oil and natural gas reserves.

o. most important, almost all submissions stressed that the prime and perhaps the only requirement was to create a stable economic environment which provides a competitively priced opportunity for companies engaged in the oil and natural gas industry in British Columbia in comparison to Alberta.

Fewer submissions were received by the Commission for the 1976 hearing than in 1975 (twenty-seven as against fifty-seven) with many of the smaller producers choosing to endorse an association report, such as that of the Canadian Petroleum Association rather than make an individual submission.

The Commission Report following the 1976 hearing was not available in time for comment. It is sufficient to say that the operation of the Commission itself in its two Natural Gas Field Price and Incentives Inquiries attracted the most public attention and participation in the Commission's three years of operation. Its probing was thorough and its assimilation of material included the most current information available on industry activity in British Columbia. In 1975 its findings and recommendations were generally implemented by the government with the positive effect of initiating renewed industry activity in the province. Basically, this renewed activity was felt to stem from the Exploration 
and Development Fund Credit schemes. The true measure of the program's effectiveness now seems questionable and the 1976 Report will be viewed with great interest. Irrespective of the contents of that Report the Commission has now been recognized as performing an ongoing service both to industry and the province through its Natural Gas Field Price and Incentives Inquiries and its commitment to continue monitoring the activity of the oil and natural gas industry in British Columbia.

\section{EXHIBIT A}

\section{SUMMARY OF FINDINGS AND RECOMMENDATIONS}

\section{Set Forth in Interim Report}

1. Exploration and development activity in the past season was essentially at a standstill and is projected to remain at a very low level under prevailing conditions.

2. Current natural gas and oil production are below levels that the Commission considers appropriate in the best interests of the province and such levels will further deteriorate without acceleration of activity in the industry.

3. The lack of exploration and development activity in the field has had a serious impact on the communities of Fort Nelson and Fort St. John where the service industries are located. A continuation of the depressed level of activity into another season will result in a general movement of skills and equipment out of the province with adverse long term effects on these communities and on the industry.

4. The present level of activity is low because the producing companies have, in effect, gone on strike against the current pricing arrangements.

5. Higher prices for old and new gas and increased netbacks to the industry on crude oil, together with a mechanism for revising prices and netbacks in the future are necessary incentives to provide higher levels of oil and gas production and are justified in the public interest.

6. We do not see a provincial takeover of producing oil and gas fields as a viable alternative to an active private industry. We do recommend that the provincial government establish a Crown corporation to engage in exploration and development of oil and gas within the province.

7. Higher prices and netbacks resulting in increased levels of exploration and development are clearly justified by the province's geological prospects for finding further major reserves of hydrocarbons.

8. The Commission recommends that the price of natural gas delivered at the wholesale level for consumption in the province be increased by approximately $254 / \mathrm{Mcf}$.

9. The Commission recommends to the government and the British Columbia Petroleum Corporation that they adopt the new prices set forth in Appendix B of this report.

10. The Commission recommends to the government and the Depart- 
ment of Mines and Petroleum Resources that the royalty schedules for crude oil be revised so as to provide a netback of approximately $\$ 1.50$ per barrel to the producer. Half of this netback should be paid only when the producer shows that he has made exploration and development expenditures in the province. In place of the current incentive for new discoveries of oil, there should be a downward revision of the royalty schedule for new oil which will provide the producer a higher netback than for old oil. As in the case of natural gas, we recommend that this Commission undertake an annual review beginning in May, 1976.

\section{Additional Recommendations in Final Report}

1. The Commission recommends that the government immediately set up a committee to resolve the various issues that must be considered in the establishment of a Crown exploration company.

2. The Commission recommends that there be improved supervision and co-ordination of environmental protection regulations through the establishment in the Department of Mines and Petroleum Resources of a group charged with this responsibility. 


\section{EXHIBIT B}

\section{WELL DRILLING DATA FROM B.C. DEPARTMENT OF MINES WELLS COMPLETED BY MONTH OF RIG RELEASE}

1975

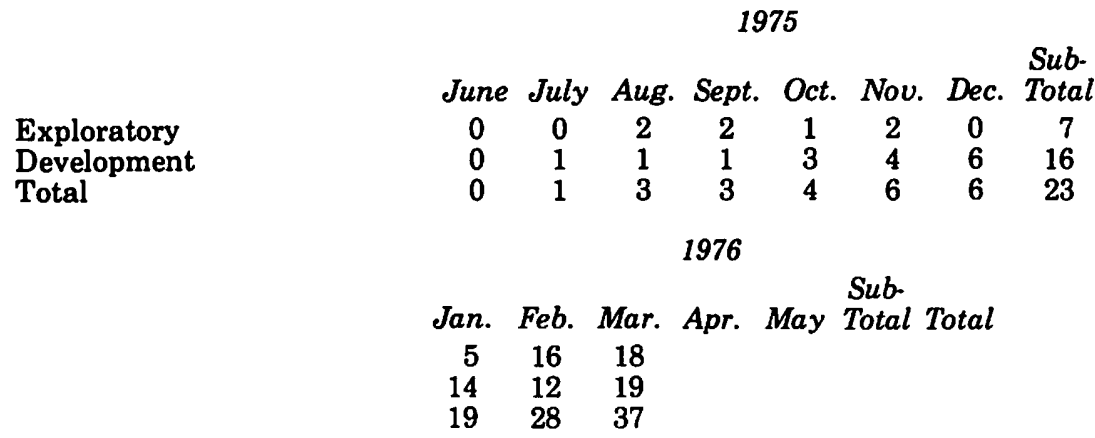

From October 1 to May 4, 132 wells were licenced by the British Columbia Department of Mines \& Petroleum Resources

\section{EXHIBIT C}

\section{MEMORANDUM OF AGREEMENT}

Re Schedule C to Novation Agreement made as of the 1st day of November, 1973, between

(herein called the "Producer"), British Columbia Petroleum Corporation (herein called "BCPC") and Westcoast Transmission Company Limited, re Contract dated

WHEREAS each page of the material constituting Schedule $C$ to the Novation Agreement constitutes also an unspecified part of each contract ("Gas Purchase Contract") referred to in the heading to such Schedule;

AND WHEREAS the parties hereto wish to amend Schedule $\mathrm{C}$ to the Novation Agreement and to specify its situation, as amended pursuant hereto, in each Gas Purchase Contract of which it forms a part;

AND WHEREAS Schedule D to the Novation Agreement constitutes also an unspecified part of each Gas Purchase Contract to which such agreement relates and the parties hereto wish to specify its situation in each such Contract;

NOW THIS AGREEMENT WITNESSETH that the Producer and BCPC mutually agree as follows.

1. To amend, as of the 1st day of November, 1975, each page constituting Schedule $\mathrm{C}$ to the Novation Agreement by deleting "Year of Delivery" and "Cents per Mcf" and everything which appears thereunder (including each paragraph beneath the table of prices) and substituting therefor:

The price for gas delivered pursuant hereto on or after the 1st day of November, 1975, shall be:

(a) 554 for each mcf of residue gas derived from New Gas delivered hereunder, and 
(b) 354 for each mcf of residue gas dexived from Old Gas delivered hereunder, provided that for each mcf of residue gas derived from Old Gas so delivered on or after the 1st day of November, 1975, the buyer shall

(i) hold back out of the purchase price otherwise payable the sum of 154 ,

(ii) record a credit (herein called a "Credit") in favour of the seller, which Credit shall be subject to the terms of Schedule $C$ to this Agreement, and

(iii) confirm to the seller that such Credit has been so recorded (such confirmation constituting full satisfaction by the buyer of the portion of the purchase price held back as aforesaid);

it being agreed that New Gas is raw gas which comes within one of the categories (that is, one of the classes of gas described in the price policy letter dated November 21,1974 ) which as of the 1st day of January, 1975, took a price on sale to the buyer of not less than $23 \%$ per mcf of residue gas derived therefrom, and Old Gas is raw gas which does not qualify as New Gas.

2. That each page of Schedule $C$ to the Novation Agreement as amended hereby shall constitute Schedule B (Schedule $\mathrm{B}^{1}$ where there is a Schedule B already) of each Gas Purchase Contract referred to in the heading to such page.

3. That Schedule D of the Novation Agreement shall constitute Schedule

D to each Gas Purchase Contract to which such Agreement relates.

IN WITNESS WHEREOF the parties hereto have caused these presents to be executed as of the 1st day of November, 1975.

\section{Definitions}

\section{SCHEDULE C}

(A) "Allowable Cost" means any cost (to the extent that same is reasonable in amount) incurred in the doing of any activity which constitutes "Allowable Work";

(i) and includes the cost of machinery and equipment installed in the course of doing Allowable Work and the cost of replacing and repairing such machinery and equipment to the extent that each such cost can, in accordance with generally recognized accounting principles, be classified as a capital expenditure (whether or not it has been so classified by the Person incurring such cost);

(ii) but does not include

(a) any cost incurred in acquiring funds to finance such activity (for example, interest, stand-by fees, or any allowance, interest, stand-by fees, or any allowance for the cost of money),

(b) any cost for administration or supervision otherwise chargeable to such activity (other than salaries and wages of individuals engaged in supervision at the field site of the Allowable Work),

(c) any cost to the extent that it is recoverable by or on behalf of the Person who has incurred same, whether through a policy of insurance, as damages, or for any other reason;

provided however, that the amount of each Allowable Cost calculated hereunder may be increased by the Holder making an application under paragraph 4 hereof by ten per cent to 
compensate for the disallowance under subclause $1(\mathrm{~A})(\mathrm{ii})(\mathrm{b})$ hereof.

(b) "Allowable Work" means any of the following, or any part thereof:

(i) drilling or completing a Well which is an exploratory, development, structure test, water source, pressure maintanance, injection, storage or water disposal well;

(ii) abandoning, or suspending, any type of well specified in clause 1(B)(i) hereof if such abandonment or suspension (as the case may be) is completed within thirty months after such well was spudded;

(iii) installing compression facilities in respect of any Well which produces gas which is sold to the Buyer;

(iv) installing pipelines, dehydrators, pumps or meters at any point between the wellhead and the point where gas is delivered by the producer to the Buyer if such installation is necessary to bring gas on stream;

(v) replacing, wholly or partly, the tubing or casing in the Christmas tree installed on, a Well;

(vi) any other work which is done in connection with, and at the site of, a Well or a Pool (such as the doing of a work over or the installation of a conservation plant to extract gas from petroleum produced from such Well or Pool) to the extent that the cost of such work can, in accordance with generally accepted accounting principles, be classified as a capital expenditure (whether or not it has been so classified by the Person doing such work);

(vii) the field work portion of any geophysical or geological survey;

to the extent that the same is done within the Province of British Columbia.

(C) "Buyer" means British Columbia Petroleum Corporation.

(D) "Credit" is a right to receive, subject to the terms of this Schedule, a certain sum of money from the Buyer as part of the consideration for natural gas sold to the Buyer by the Person who holds title to such right or by that Person's predecessor in title to such right; and "Credits" means two or more of such rights.

(E) "Credit Year" means a period of time commencing at 8 a.m. (Pacific Standard Time) on any November 1 and ending at 8 a.m. (Pacific Standard Time) on the November 1 next following its commencement, and "Credit Years" means two or more of such periods.

(F) "Face Value" has the meaning specified in paragraph 8 hereof.

(G) "Holder" means the Seller or any Person who is recorded pursuant to paragraph 3 hereof as a successor in title to any of the Credits issued pursuant hereto.

(H) "Person" includes a corporation, howsoever incorporated, and a partnership, howsoever constituted.

(I) "Seller" means each Person named as such in the gas purchase contract of which this Schedule forms a part. 
(J) For the purposes of this Schedule, a Credit is conclusively deemed to have been earned when title to the Old Gas to which it relates passes to the Buyer.

(K) Definitions set forth in the Agreement of which this Schedule forms a part are applicable hereto except to the extent that they are inconsistent with the terms defined herein.

\section{Confirmation of Credits}

The Buyer shall, from time to time, upon request of any Holder, deliver to or to the order of such Holder, a written instrument specifying a number (which may be all or, if the Holder so requests, some only) of the Credits which

(A) Are registered in the name of the Holder pursuant to the provisions of the gas purchase contract of which this Schedule forms a part, or paragraph 3 of this Schedule;

(B) Were earned in any one Credit Year, and

(C) Have not been redeemed and are not the subject of an application made under paragraph 4 of this Schedule, and

(D) Have not expired.

\section{Transfer of Credits}

No Credit may be assigned, transferred or otherwise disposed of in whole or in part, except by the Holder completing and executing the transfer form, a copy of which appears as Appendix One hereto, and surrendering same to the transferee, and if execution of such form by or on behalf of the Holder making such transfer is proved, the Buyer shall record the transferee as Holder in respect of the number of Credits transferred, provided that the Buyer:

(A) May treat the execution of a transfer form as proved as aforesaid if such form bears an impression which purports to be the corporate or common or personal seal of the Person who is named in the transfer as the Transferor;

(B) Is not required to record or otherwise recognize in respect of any Credit any charge, encumbrance or right of any nature which is adverse to the interests of the Person who is registered as the Holder of such Credit.

\section{Redemption of Credits}

A Holder may apply for redemption of some or all of the Credits which are recorded in the name of such Holder, by presenting the Buyer:

(A) An application for redemption of Credits, executed by the Holder or an officer thereof, and

(B) A statutory declaration of that Holder or an officer thereof, In accordance with the forms which appear as Appendix Two hereto.

\section{Amount Payable on Redemption}

A Holder, upon making an application for redemption in accordance with paragraph 4 hereof, shall be entitled, subject to the terms of this Schedule, to payment of a sum of money equal to the Face Value (as of the date upon which such application is received by the Buyer) of the Credits specified in the claim referred to in subparagraph 4(A) hereof, to a maximum of seventy-five per cent of the Allowable Costs incurred by that Holder in doing that part of the Allowable Work set forth in the 
statutory declaration and done during the period:

(A) Composed of the Credit Year current at the time of receipt by the Buyer of such application and the two immediately-preceding Credit Years, or

(B) Commencing September 1, 1975, and continuing to the date of receipt of such application as aforesaid,

whichever is the shorter.

\section{Payment on Redemption}

Whenever an application is made under paragraph 4 hereof, the Buyer shall forthwith determine the extent of the payment, if any, to which the Holder who made the application is entitled, and shall make such payment as quickly as reasonably possible, provided:

(A) That if the Buyer refuses to make payment in whole or in part, it shall specify its reasons for such refusal, and

(B) That the Buyer may require the Holder who made the application to submit additional material in further explanation or support of the application to the extent reasonably required to enable the Buyer to make the aforesaid determination, and

(C) That nothing herein shall require the Buyer to make any payment hereunder prior to April 1, 1976.

\section{Effect of Payment}

Payment by the Buyer pursuant to paragraph 6 hereof shall constitute redemption of that number of Credits, the Face Value of which equals the payment, and whenever the Face Value of the Credits specified in the schedule referred to in subparagraph 4(B) hereof is greater than the amount payable under paragraph 5 hereof, the Holder shall, upon the request of the Buyer, nominate the Credits he wishes to surrender.

\section{Face Value}

The Face Value of each Credit is an amount which shall vary (during periods related to the date of its creation) as follows:

\section{Period}

Face Value

(One) Credit Year during which Credit was created and the first Credit Year thereafter

(Two) Second Credit Year thereafter

provided however, that whenever one-half or more of all Credits earned by the Seller in any one Credit Year (including Credits earned by the Seller under gas purchase contracts other than the one of which this Schedule forms a part) are redeemed during Period One above, then the Face Value of each Credit earned by the Seller during said Credit Year but not redeemed during Period One (such Credit being referred to herein as a "Locked-in Credit") shall remain at 154 throughout Period Two and Period Three. Each Credit expires at the end of the Third Period and may not be redeemed thereafter.

9. Credit to Buyer

Whenever any "Covered Machinery" (that is equipment or machinery the cost of which or the cost of the installation or the 
repairing of which was used in whole or in part as the basis for redemption of any Credit hereunder) is removed from the Province of British Columbia (other than temporarily in order to repair same), each Holder who made such redemption shall forthwith give notice to the Buyer setting forth:

(A) A description of the Covered Machinery;

(B) A statement of all Allowable Costs incurred in respect of the Covered Machinery to the extent that such costs formed the basis of any redemption hereunder pursuant to an application under paragraph 4 received by the Buyer within forty-eight months prior to the date of the aforesaid removal; and

(C) The date of each statutory declaration submitted under paragraph 4 hereof which includes any of the Allowable Costs referred to in subparagraph $9(B)$ hereof;

and such Holder shall refund to the Buyer that part of the moneys received on redemption attributable to the Allowable Costs referred to in subparagraph $9(\mathrm{~B})$ hereof less an allowance for use of the Covered Machinery prior to its removal, whereupon the Holder shall be entitled to reissue of the Credits redeemed by virtue of the Allowable Costs referred to in subparagraph $9(B)$ hereof (subject to an adjustment for any allowance made as aforesaid), provided that whenever Credits of two or more different Face Values were redeemed upon such application which included the Allowable Costs attributable to such Covered Machinery, Credits of differing Face Values shall be reissued in the same relative proportions as they were redeemed.

\section{Arbitration}

Whenever the parties hereto are unable to settle any matter or question which arises out of the application or interpretation of this Schedule, including, without limiting the generality of the foregoing:

(A) Whether any cost or work set forth in such declaration is properly included in whole or in part as either an Allowable Cost or an Allowable Work respectively, or

(B) The amount of any refund or allowance or the number or vintage of Credits to be reissued under paragraph 9 hereof;

then the matter which the parties are unable to settle as aforesaid may be, at the instance of either of them, submitted to arbitration in accordance with the provisions of the Arbitration Act of the Province of British Columbia. 


\section{APPENDIX ONE TO SCHEDULE C OF GAS PURCHASE CONTRACT*}

\section{TRANSFER OF CREDITS}

\section{Date}

The Transferor, for valuable consideration received, hereby transfers to ("Transferee")

Credits which are subject to the terms identified on the reverse side hereof," and are more particularly described as follows.

NUMBER (AMOUNT) OF SERIAL NUMBERS OF CREDITS TRANSFERRED CREDITS TRANSFERRED

LOCKED IN CREDITS

(IDENTIFIED BY

SERIAL NUMBERS)

\section{(Transferor)}

\section{APPLICATION TO REGISTER}

\section{(Date)}

The Transferee hereby applies to BRITISH COLUMBIA

PETROLEUM CORPORATION to be registered as Holder of the

Credits transferred by this instrument and agrees, as

a condition of such registration, that the Credits

are subject to the terms identified on the reverse side hereof.

\section{(Transferee)}

* The terms referred to in the form of transfer of Credits on the reverse side hereof are set forth in the gas purchase contract pursuant to which each Credit transferred was earned. A copy of such schedule may be obtained from the British Columbia Petroleum Corporation, 6th Floor, 1199 West Hastings Street, Vancouver, B.C., V6E 3T5. Telephone 685-0411; Telex 04-54530. 


\section{APPENDIX TWO TO SCHEDULE C OF GAS PURCHASE CONTRACT}

\section{STATUTORY DECLARATION}

Re application for redemption of Credits by

("Applicant") dated the day of 19

I, (name)

of in the City of , Province of

1. I am the of the Applicant and have personal knowledge of the matters herein deposed to, unless otherwise stated.

2. I have made such enquiries and examinations of the records of the Applicant as I judged were reasonably necessary to enable me to verify the accuracy of the application for redemption of Credits attached hereto and marked " $\mathrm{A}$ ", and to the best of my knowledge, information and belief:

(a) The said application is correct in every material respect, and

(b) The Applicant has no agreement by which it is entitled to recover any of the costs set forth in Item 4 of the application from any person, persons or body corporate;

and I make this solemn declaration conscientiously believing it to be true and knowing that it is of the same force and effect as if made under oath.

DECLARED before me

at

this day of

19

A NOTARY PUBLIC in and for the Province of

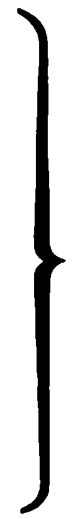




\section{APPLICATION FOR REDEMPTION OF CREDITS}

by

dated

To: British Columbia Petroleum Corporation

6th Floor, 1199 West Hastings St.

Vancouver, B.C. V6E 3T5

Gentlemen:

The Applicant hereby applies to redeem Credits, particulars of the application being as follows.

1. Description of Work on which application is based

2. Location of Work

3. Period of time during which Work was done

4. Costs (which Applicant regards as Allowable Costs) incurred in respect of aforesaid Work

5. Schedule of Credits

Number (Amounts of Credits

Surrendered

Serial Numbers of Credits to be Surrendered

The Applicant agrees that it is a condition of redemption of Credits hereunder that no part of the costs referred to in this application is recoverable by the Applicant from any person, or persons or body corporate.

Applicant

Per: 